\title{
An Atlas for Rammed Earth Building Thermal Performance in Australia Climates
}

\author{
Dong Chen ${ }^{1}$, Zhengen Ren $^{1}$
}

\author{
${ }^{1}$ CSIRO Land and Water, Melbourne, Australia
}

\begin{abstract}
To understand whether the existing house energy star rating system in Australia discriminates against rammed earth houses, simulations were carried out for two sample houses each in 69 local climates at different heating and cooling thermostat temperatures with the original wall systems and with the walls replaced by rammed earth walls. Results showed that rammed earth houses may have been discriminated for climate regions with mean ambient winter temperature between 10.0 and $15.0^{\circ} \mathrm{C}$ for the population group who operates heating thermostat temperature at around $15^{\circ} \mathrm{C}$ during winter. The findings of this study can provide useful information for building regulators on the potential impact of the existing as well as modified thermostat settings in house energy star rating software.
\end{abstract}

\section{Introduction}

In Australia, the Nationwide House Energy Rating Scheme (NatHERS) has been gradually adopted by state and territory governments and building regulators over the last two decades (Delsante, 2005). The increase in the house energy efficiency stringency has contributed to the flatting or declining of residential sector energy consumption in Australia in recent years (DOEE, 2018).

In supporting the NatHERS scheme, a dynamic building simulation tool AccuRate is used as the benchmark software for NatHERS star rating for houses to demonstrate compliance with Australian national construction code (NCC) energy efficiency requirements. The AccuRate software was developed by coupling a frequency response building thermal model and a multizone air flow model for heating and cooling energy requirement calculation of residential buildings (Walsh \& Delsante, 1983; Delsante, 2005; Ren \& Chen, 2010). Taking into account the local climate and building fabrics, AccuRate automatically switches the building operation between mechanical air conditioning and natural ventilation operation and calculates hourly heating and cooling energy requirement over the period of one year. Then, AccuRate assigns the house a NatHERS star rating from zero to ten based on the calculated total annual heating and cooling energy requirement per $\mathrm{m}^{2}$ conditioned floor area. The more stars, the less likely the occupants need cooling or heating to stay comfortable. Occupants of a 10 star house are unlikely to need any artificial cooling or heating. Currently, most of the state and territories require a minimum 6 star NatHERS rating for new houses in Australia.

For the calculation of building heating and cooling energy requirement, thermostat settings are commonly set according to standards such as ASHRAE 55-2013 (ASHRAE, 2013) for achieving required occupant thermal comfort. The heating and cooling thermostat settings used in AccuRate are specified in NatHERS software accreditation protocol (NatHERS, 2012). For living spaces, a heating thermostat setting of $20^{\circ} \mathrm{C}$ is used. For sleeping spaces, heating thermostat setting are $18^{\circ} \mathrm{C}$ from 7:00 to $9: 00$ and $16: 00$ to $24: 00$, and $15^{\circ} \mathrm{C}$ from $24: 00$ to $7: 00$. The cooling thermostat is set equal to the neutral temperature of January (the middle month of the summer in the southern hemisphere) for the corresponding climate zone. It is also assumed that cooling is triggered when indoor air temperature is $2.5^{\circ} \mathrm{C}$ above the neutral temperature which corresponds to $90 \%$ acceptability limit of the ASHRAE adaptive thermal comfort model (ASHRAE, 2013). The cooling thermostat settings, although not exactly corresponding to the ASHRAE adaptive thermal comfort model (ASHRAE, 2013), are based on the understanding that acceptable thermal conditions vary with the local climates.

Thermostat settings can significantly affect the calculation of heating and cooling energy requirement and thus impact on whether or not a house design obtains building approval. James et al (1996) simulated a typical house in three Florida cities and showed that cooling energy can be reduced over $20 \%$ with per ${ }^{\circ} \mathrm{C}$ increase in the thermostat temperature. Manning et al (2007) evaluated experimentally a pair of identical twin houses at the Canadian Centre for Housing Technology and showed that cooling energy reduction can be over $10 \%$ with per ${ }^{\circ} \mathrm{C}$ increase in the thermostat temperature. Recently, using AccuRate simulations, Ren \& Chen (2017) demonstrated that relaxing the cooling triggering temperature from $2.5^{\circ} \mathrm{C}$ to $3.5^{\circ} \mathrm{C}$ above the neutral temperature (corresponding to $80 \%$ acceptability limit of the ASHRAE adaptive thermal comfort model) reduces $40 \%$ of the calculated space cooling energy requirement in regions with hot summer climates (e.g. Alice Springs) for a heavyweight double brick cavity construction house. For a high-set lightweight weatherboard house, such a relaxing in the cooling triggering temperature can result in $25 \%$ reduction in the cooling energy requirement and a 2 star increase in tropical regions (e.g. Darwin). 
Consequently, the triggering temperature and thermostat set point temperature in AccuRate can impact on the construction types of the residential building sector in Australia. Considering that the average service life of a house in Australia is around 60 years, the impact of the thermostat settings used in NatHERS star rating software can be significant over many years to come on the Australian residential sector energy efficiency and greenhouse gas emissions.

Although monitored heating and cooling energy generally confirms the reduction trend for houses built to higher energy efficiency star ratings (O'Leary et al, 2016), there are criticisms on NatHERS software tools. One longstanding criticism is that by using the above mentioned fixed heating and cooling thermostat settings, NatHERS energy rating discriminates against the application of climate responsive house construction types such as traditional heavyweight rammed earth buildings and lightweight tropical houses (Soebarto, 2000; Kordjamshidi and King, 2009; Williamson et al, 2010; Daniel et al, 2015a; Daniel, 2017).

Rammed earth is a sustainable construction material and has been widely used in numerous historical structures. In Australia, small communities of rammed earth house owners/builders are still very active. In several previous studies in Australia (Soebarto, 2000; Williamson et al, 2010), measured energy consumption showed that rammed earth houses are more energy efficient in comparison with average modern houses. However, the relatively low thermal resistance, $\mathrm{R}$-value at 0.24 $\left(\mathrm{m}^{2} \cdot{ }^{\circ} \mathrm{C} / \mathrm{W}\right)$ for a $300 \mathrm{~mm}$ thick wall, has made rammed earth house designs very difficult to comply with NCC using NatHERS star rating. This noted difference between measured energy consumptions and NatHERS star rating for rammed earth houses has been attributed to the fact that occupants of rammed earth houses are generally more ecocentric (Daniel et al, 2015b). They considered conditions comfortable often outside of the accepted adaptive thermal comfort limits (Daniel et al, 2015b) with which the thermostat settings of NatHERS star rating are based on. In other words, occupants of rammed earth houses generally operate their houses at different thermostat settings to those used in NatHERS star rating. It has been suggested that the mandatory NatHERS star rating should consider the atypical preference of such group of population (Daniel et al, 2015b) who genuinely live more energy efficiently in traditional houses such as rammed earth houses.

So far, there is no systematic study on the impact of thermostat settings on the energy performance of rammed earth houses when compared with normal modern house designs in different Australian climates. In this study, simulated house heating and cooling energy requirements were compared in all 69 NatHERS climate zones (which cover the entire Australia) between normal modern houses and rammed earth houses using AccuRate with the same floor plans and realistic thermostat setting ranges based on recent monitoring studies. This study tries to answer the question whether the existing thermostat settings in NatHERS software discriminates against rammed earth houses. It also provides information for building regulators on the potential impact of modifying existing thermostat settings in NatHERS software tools.

\section{Methodology}

\section{Climate zones}

Australia has a wide range of climates from relatively cold alpine climate to hot humid tropical climate. Eight National Construction Code (NCC) climate zones (CZ) are defined by the Australian Building Codes Board (ABCB) as listed in Table 1. Table 1 also includes the corresponding Köppen climate group for these eight NCC) climate zones. For NatHERS star rating using building simulation software, a more detailed 69 local NatHERS climate zones (CZs) are used. AccuRate contains the Typical Meteorological Year (TMY) weather files for the 69 NatHERS CZs.

Table 2 shows the NatHERS CZs with its corresponding NCC CZ and the existing cooling thermostat temperatures.

Table 1: NCC climate zones and their representative cities

\begin{tabular}{|c|c|c|c|}
\hline $\begin{array}{c}\text { NCC } \\
\text { climate } \\
\text { zone }\end{array}$ & $\begin{array}{c}\text { Represent } \\
\text { City }\end{array}$ & Description & $\begin{array}{c}\text { Köppen } \\
\text { climate group }\end{array}$ \\
\hline Zone 1 & Darwin & $\begin{array}{c}\text { Hot humid summer, } \\
\text { warm winter }\end{array}$ & A(tropical) \\
\hline Zone 2 & Brisbane & $\begin{array}{c}\text { Warm humid } \\
\text { summer, mild winter }\end{array}$ & C(temperate) \\
\hline Zone 3 & $\begin{array}{c}\text { Alice } \\
\text { Springs }\end{array}$ & $\begin{array}{c}\text { Hot dry summer, } \\
\text { warm winter }\end{array}$ & B(dry) \\
\hline Zone 4 & Mildura & $\begin{array}{c}\text { Hot dry summer, } \\
\text { cool winter }\end{array}$ & $\mathrm{B}$ (dry) \\
\hline Zone 5 & Sydney & Warm temperate & $\mathrm{C}($ temperate) \\
\hline Zone 6 & Melbourne & Mild temperate & C(temperate) \\
\hline Zone 7 & Canberra & Cool temperate & C(temperate) \\
\hline Zone 8 & Cabramurra & Alpine & E(polar) \\
\hline
\end{tabular}

\section{Sample houses}

Since October 2014, NatHERS house energy efficiency star rating using AccuRate has been centrally certified and stored in the HStar web portal (https://www.hstar.com.au) managed by the Commonwealth Scientific and Industrial Research Organisation (CSIRO) for facilitating verifying, auditing, analysing, and research. In Australia, over 70\% of the dwellings are low-rise detached houses. In this study, two certified house designs were selected for each NatHERS CZ from the HStar database. Houses with brick veneer external wall construction were selected first considering that brick veneer construction is the most commonly used in many regions in Australia. If there is not enough brick veneer houses in the particular climate zone, houses with other construction types were selected. For those climate zones with less than two certified house designs in the HStar database, the house designs from neighbouring NatHERS CZs within the same NCC CZ were used with the assumption that house designs in nearby NatHERS CZs are similar. As shown in Table 2, a 
total of 138 real certified house designs were thus selected in this study with a variety of external wall types including 82 with brick veneer, 17 with concrete block wall, 23 with fibre-cement wall, 11 with steel sheet wall, 4 with timber weatherboard, and 1 with double brick wall. These houses range from two bedrooms to seven bedrooms, with floor areas range from $88 \mathrm{~m}^{2}$ to $621 \mathrm{~m}^{2}$ as shown in Table 2 . All the houses have concrete slab floors with 123 single storey houses and 15 double storey houses. So, in theory, the external and internal walls can be readily replaced with rammed earth walls. Table 3 lists the thermal resistances and the heat capacities of the wall systems used in this study. It is seen that the concrete block wall and the rammed earth wall have the lowest thermal resistances among all the wall systems investigated in this study. On the other hand, the rammed earth wall has the highest heat capacity among all the wall systems.

Table 2: House wall types, floor areas and existing cooling thermostat temperature in each NatHERS climate zone.

\begin{tabular}{|c|c|c|c|c|}
\hline $\begin{array}{l}\text { NatHERS } \\
\text { CZ (NCC } \\
\text { CZ) }\end{array}$ & City Name & $\begin{array}{l}\text { Sample } \\
\text { House } \\
\text { External } \\
\text { Wall } \\
\text { Type }\end{array}$ & $\begin{array}{l}\text { Sample } \\
\text { House } \\
\text { Floor } \\
\text { Area } \\
\left(\mathbf{m}^{2}\right)\end{array}$ & $\begin{array}{l}\text { Existing } \\
\text { Cooling } \\
\text { Thermostat } \\
\text { temperature } \\
\left({ }^{\circ} \mathrm{C}\right)\end{array}$ \\
\hline $1(1)$ & Darwin & $\mathrm{CB}, \mathrm{CB}$ & 148,181 & 26.5 \\
\hline $2(1)$ & Pt Hedland & SS,BV & 262,214 & 27 \\
\hline $3(3)$ & Longreach & $\mathrm{BV}, \mathrm{WB}$ & 234,307 & 27 \\
\hline $4(3)$ & Carnarvon & $\mathrm{CB}, \mathrm{CB}$ & 184,105 & 26 \\
\hline $5(1)$ & Townsville & $\mathrm{CB}, \mathrm{CB}$ & 170,281 & 26.5 \\
\hline $6(3)$ & Alice Springs & $\mathrm{CB}, \mathrm{CB}$ & 211,223 & 26.5 \\
\hline $7(2)$ & Rockhampton & $\mathrm{BV}, \mathrm{FC}$ & 198,139 & 26 \\
\hline $8(4)$ & Moree & $\mathrm{BV}, \mathrm{SS}$ & 289,180 & 26 \\
\hline $9(2)$ & Amberley & $\mathrm{BV}, \mathrm{BV}$ & 193,314 & 26 \\
\hline $10(2)$ & Brisbane & $\mathrm{BV}, \mathrm{BV}$ & 621,238 & 25.5 \\
\hline $11(2)$ & Coffs Harbour & $\mathrm{BV}, \mathrm{BV}$ & 230,261 & 25 \\
\hline $12(5)$ & Geraldton & $\mathrm{BV}, \mathrm{BV}$ & 212,243 & 25 \\
\hline $13(5)$ & Perth & FC,BV & 189,327 & 25 \\
\hline $14(7)$ & Armidale & $\mathrm{FC}, \mathrm{BV}$ & 221,103 & 24 \\
\hline $15(5)$ & Williamtown & $\mathrm{BV}, \mathrm{BV}$ & 249,234 & 25 \\
\hline $16(5)$ & Adelaide & $\mathrm{BV}, \mathrm{BV}$ & 137,269 & 25 \\
\hline $17(5)$ & Sydney & $\mathrm{BV}, \mathrm{BV}$ & 297,168 & 25.5 \\
\hline $18(6)$ & Nowra & $\mathrm{BV}, \mathrm{BV}$ & 245,451 & 24.5 \\
\hline $19(3)$ & Charleville & $\mathrm{BV}, \mathrm{WB}$ & 234,307 & 27 \\
\hline $20(4)$ & Wagga & $\mathrm{BV}, \mathrm{BV}$ & 195,304 & 25 \\
\hline $21(6)$ & Melbourne & $\mathrm{AC}, \mathrm{BV}$ & 374,227 & 24 \\
\hline $22(6)$ & East Sale & $\mathrm{BV}, \mathrm{BV}$ & 196,141 & 23 \\
\hline $23(7)$ & Ti Tree Bend & $\mathrm{BV}, \mathrm{WB}$ & 248,91 & 22.5 \\
\hline $24(7)$ & Canberra & $\mathrm{BV}, \mathrm{BV}$ & 418,195 & 24 \\
\hline $25(8)$ & Cabramurra & $\mathrm{FC}, \mathrm{BV}$ & 216,271 & 23 \\
\hline $26(7)$ & Hobart & $\mathrm{BV}, \mathrm{BV}$ & 322,221 & 23 \\
\hline $27(4)$ & Mildura & $\mathrm{BV}, \mathrm{BV}$ & 162,317 & 25 \\
\hline $28(6)$ & Richmond & $\mathrm{BV}, \mathrm{BV}$ & 224,197 & 24.5 \\
\hline $29(1)$ & Weipa & $\mathrm{FC}, \mathrm{FC}$ & 116,155 & 26 \\
\hline $30(1)$ & Wyndham & SS,SS & 212,154 & 27.5 \\
\hline $31(1)$ & Willis Island & SS,SS & 154,375 & 26.5 \\
\hline $32(1)$ & Cairns & $\mathrm{CB}, \mathrm{CB}$ & 211,170 & 26.5 \\
\hline $33(1)$ & Broome & SS,SS & 212,154 & 27 \\
\hline $34(1)$ & Learmonth & SS,BV & 262,214 & 26.5 \\
\hline $35(2)$ & Mackay & $\mathrm{BV}, \mathrm{FC}$ & 198,139 & 26 \\
\hline $36(2)$ & Gladstone & $\mathrm{BV}, \mathrm{FC}$ & 198,139 & 26 \\
\hline $37(3)$ & Halls Creek & $\mathrm{CB}, \mathrm{CB}$ & 184,105 & 27 \\
\hline $38(3)$ & Tennant Creek & $\mathrm{CB}, \mathrm{FC}$ & 280,243 & 27 \\
\hline $39(3)$ & Mt Isa & $\mathrm{CB}, \mathrm{FC}$ & 280,243 & 27 \\
\hline $40(3)$ & Newman & $\mathrm{CB}, \mathrm{CB}$ & 184,105 & 28 \\
\hline $41(4)$ & Giles & $\mathrm{BV}, \mathrm{FC}$ & 395,211 & 27.5 \\
\hline $42(4)$ & Meekatharra & $\mathrm{BV}, \mathrm{FC}$ & 395,211 & 28 \\
\hline
\end{tabular}

\begin{tabular}{|c|c|c|c|c|}
\hline $43(4)$ & Oodnadatta & $\mathrm{BV}, \mathrm{BV}$ & 119,270 & 27 \\
\hline $44(4)$ & Kalgoorlie & $\mathrm{BV}, \mathrm{BV}$ & 385,395 & 26 \\
\hline $45(4)$ & Woomera & $\mathrm{BV}, \mathrm{BV}$ & 119,270 & 26 \\
\hline $46(4)$ & Cobar & $\mathrm{BV}, \mathrm{FC}$ & 170,267 & 26.5 \\
\hline $47(4)$ & Bickley & $\mathrm{BV}, \mathrm{BV}$ & 384,252 & 24.5 \\
\hline $48(4)$ & Dubbo & $\mathrm{BV}, \mathrm{BV}$ & 406,379 & 25 \\
\hline $49(4)$ & Katanning & $\mathrm{BV}, \mathrm{BV}$ & 252,152 & 24.5 \\
\hline $50(5)$ & Oakey & SS,BV & 249,88 & 25 \\
\hline $51(5)$ & Forrest & FC,FC & 188,161 & 25.5 \\
\hline $52(5)$ & Swanbourne & $\overline{F C, F C}$ & 237,208 & 25 \\
\hline $53(5)$ & Ceduna & $\mathrm{BV}, \mathrm{FC}$ & 171,161 & 24.5 \\
\hline $54(5)$ & Mandurah & $\mathrm{FC}, \mathrm{FC}$ & 287,175 & 25 \\
\hline $55(5)$ & Esperance & FC,FC & 188,175 & 24 \\
\hline $56(5)$ & $\begin{array}{l}\text { Sydney } \\
\text { Airport }\end{array}$ & $\mathrm{BV}, \mathrm{BV}$ & 297,168 & 24.5 \\
\hline $57(6)$ & Manjimup & $\mathrm{BV}, \mathrm{BV}$ & 338,276 & 23.5 \\
\hline $58(6)$ & Albany & $\mathrm{BV}, \mathrm{BV}$ & 338,276 & 23.5 \\
\hline $59(6)$ & Mt Lofty & $\mathrm{BV}, \mathrm{BV}$ & 165,265 & 23 \\
\hline $60(6)$ & $\begin{array}{l}\text { Melbourne } \\
\text { Airport }\end{array}$ & $\mathrm{BV}, \mathrm{BV}$ & 330,265 & 24 \\
\hline $61(6)$ & Mt Gambier & $\mathrm{BV}, \mathrm{BV}$ & 211,264 & 23.5 \\
\hline $62(6)$ & Moorabbin & $\mathrm{BV}, \mathrm{BV}$ & 307,195 & 24 \\
\hline $63(6)$ & Warrnambool & $\mathrm{BV}, \mathrm{BV}$ & 141,198 & 23 \\
\hline $64(6)$ & Cape Otway & $\mathrm{BV}, \mathrm{BV}$ & 227,264 & 23 \\
\hline $65(7)$ & Orange & $\mathrm{BV}, \mathrm{BV}$ & 156,269 & 23 \\
\hline $66(7)$ & Ballarat & $\mathrm{BV}, \mathrm{BV}$ & 253,211 & 23.5 \\
\hline $67(7)$ & Low Head & $\mathrm{BV}, \mathrm{WB}$ & 248,91 & 23 \\
\hline $68(7)$ & $\begin{array}{l}\text { Launceston } \\
\text { Airport }\end{array}$ & $\mathrm{BV}, \mathrm{DB}$ & 248,509 & 23.5 \\
\hline $69(8)$ & Thredbo & FC,SS & 89,126 & 22.5 \\
\hline
\end{tabular}
Here:

CB: Concrete block; $\quad$ SS: Steel sheet;

BV: Brick veneer; $\quad$ WB: Weather board;

FC: Fibre-cement board; $\quad$ DB: double brick;

AC: Aerated autoclaved concrete block

Table 3: thermal resistance and the heat capacity of the wall systems used in this study ${ }^{a}$

\begin{tabular}{|c|c|c|c|}
\hline Wall system & $\begin{array}{l}\text { Material layers } \\
\text { external to internal }\end{array}$ & $\begin{array}{l}\text { Thermal } \\
\text { resistance } \\
\left(\mathbf{m}^{2} \cdot{ }^{\circ} \mathrm{C} / \mathrm{W}\right. \\
)\end{array}$ & $\begin{array}{l}\text { Heat } \\
\text { capacity } \\
\left(\mathrm{kJ} / \mathrm{m}^{2} \cdot{ }^{\circ} \mathrm{C}\right. \\
)\end{array}$ \\
\hline Brick veneer & $\begin{array}{l}\text { Brick }\left(110^{b}\right) \\
\text { Airgap }^{c} \\
\text { Insulation R0 - R3.1 } \\
\text { Plasterboard (10) }\end{array}$ & $0.40-3.91$ & 169 \\
\hline $\begin{array}{l}\text { Concrete } \\
\text { block }\end{array}$ & Concrete block (190) & 0.15 & 374 \\
\hline Fibre-cement & $\begin{array}{l}\text { Fibre-cement sheet (6) } \\
\text { Airgap }^{c} \\
\text { Insulation R0.6-R2.5 } \\
\text { Plasterboard (10) } \\
\end{array}$ & $0.83-2.73$ & 17 \\
\hline Steel sheet & $\begin{array}{l}\text { Steel sheet (1) } \\
\text { Airgap }^{c} \\
\text { Insulation R1.5-R2.5 } \\
\text { Plasterboard (10) } \\
\end{array}$ & $1.74-2.74$ & 13 \\
\hline $\begin{array}{l}\text { Timber } \\
\text { weatherboard }\end{array}$ & $\begin{array}{l}\text { Timber (18) } \\
\text { Airgap }^{c} \\
\text { Insulation R1.5-R2.5 } \\
\text { Plasterboard (10) }\end{array}$ & $1.90-2.90$ & 28 \\
\hline Double brick & $\begin{array}{l}\text { Brick (110) } \\
\text { Airgap (40) } \\
\text { Insulation (119) } \\
\text { Plasterboard (10) } \\
\end{array}$ & 3.19 & 320 \\
\hline $\begin{array}{l}\text { Rammed } \\
\text { earth }\end{array}$ & Rammed earth (300) & 0.24 & 582 \\
\hline
\end{tabular}




\section{Heating and cooling thermostat settings}

In recent years, several survey and monitoring studies on heating and cooling operation in houses have been carried out in Australia. In 2012, CSIRO did a survey and monitoring study in Brisbane, Adelaide and Melbourne (Ambroise et al, 2014). Brisbane has a subtropical climate with warm humid summer, mild winter, while both Adelaide and Melbourne have mild temperate climates. Half-hourly electricity consumption data were collected by direct monitoring electricity at the switchboard for 9 months from the beginning of June 2012 to the end of February 2013. Temperature measurements at the living areas were also taken at 30-minute intervals. Monitored data from 129 houses with reverse cycle air conditioners (A/C) were analysed (Chen et al, 2018). Figure 1 shows the relationship between the average heating and cooling switch on indoor temperature $\left(\mathrm{T}_{\text {switchon }}\right)$ and the average indoor air temperature for each house when $\mathrm{A} / \mathrm{C}$ was in operation in winter and summer. It is clear that different householders operate their houses in significantly different heating and cooling temperatures.

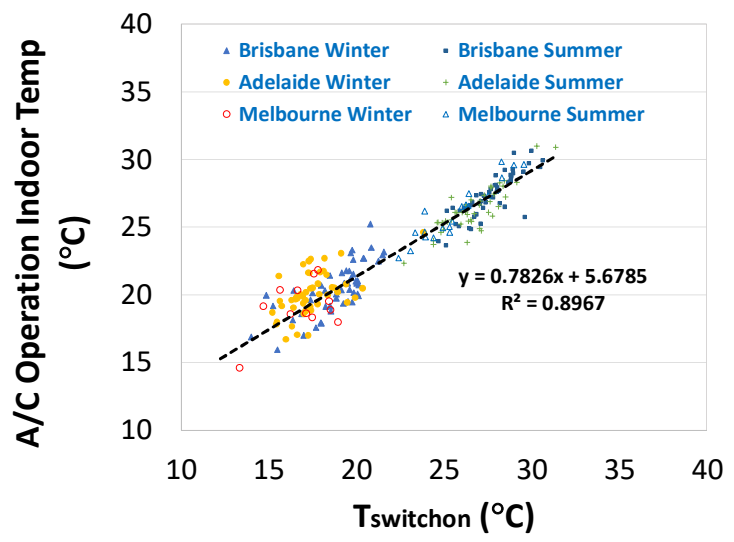

Figure 1: Relationship between average A/C switch on indoor temperature and average A/C operation indoor air temperature for each house in winter and summer (Chen et al, 2018).

Daniel et al (2015b) surveyed and monitored 20 mud brick/rammed earth houses in Melbourne and 20 partially/fully naturally ventilated houses in tropical Darwin in 2012 and 2013. Figure 2 shows the comparison between the ASHRAE55-2013 adaptive thermal comfort ranges and the comfort votes recorded. In Figure 2, there were substantial comfort votes outside the $80 \%$ acceptability limits of the adaptive thermal comfort model, especially at the cold side. This is consistent with the findings by Kim et al (2016) who monitored 27 houses in Sydney and 15 houses in Wollongong from March 2012 to March 2014. Figure 3 plotted the prevailing mean outdoor air temperature with the indoor air temperature when A/C just switched off which Kim et al (2016) argued to be the thermally comfort temperature.

These recent studies in Australian houses showed that there are groups of populations considering indoor temperatures acceptable at around $12-15^{\circ} \mathrm{C}$ in winter and around $30-32^{\circ} \mathrm{C}$ in summer. In this study, in order to provide a systematic understanding of the impact of thermostat temperatures, simulations were carried out for the 138 houses with thermostat settings extended to these relatively extreme temperature ranges.

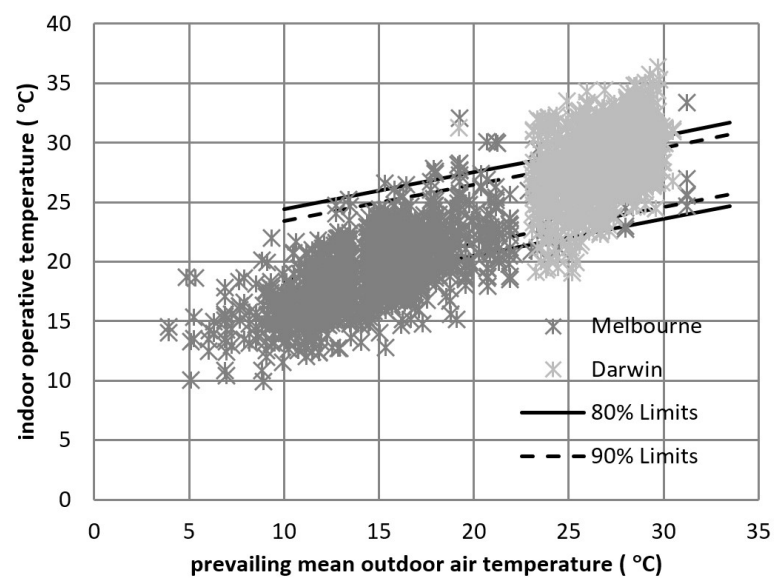

Figure 2: Indoor temperature with comfort votes plotted against the $80 \%$ and $90 \%$ acceptability ranges defined by the ASHRAE55-2013 adaptive thermal comfort model (Daniel et al, 2015b).

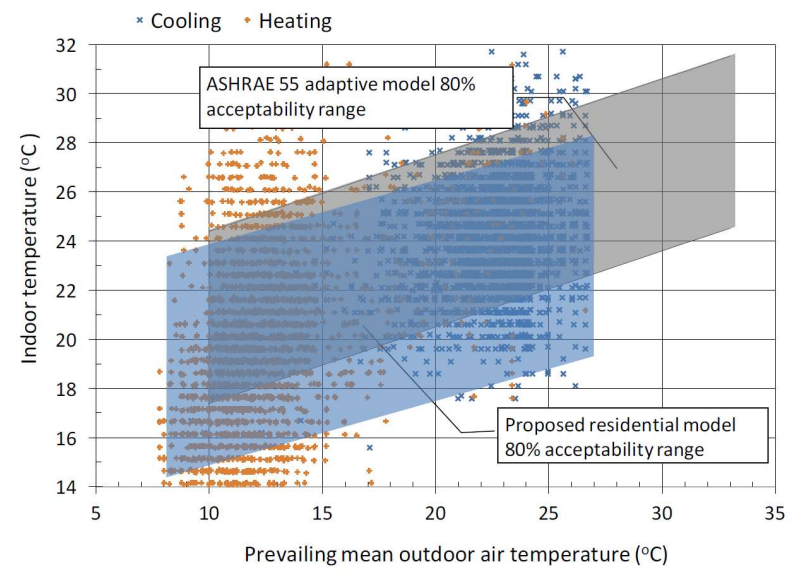

Figure 3: Indoor A/C switch off temperature plotted against the $80 \%$ acceptability range defined by the ASHRAE55-2013 adaptive thermal comfort model (Kim et al, 2016).

\section{Results and discussions}

Simulations were carried out using AccuRate for all the houses with heating thermostat at existing settings as mentioned in Introduction, and at $18^{\circ} \mathrm{C}, 17^{\circ} \mathrm{C}, 16^{\circ} \mathrm{C}$, $15^{\circ} \mathrm{C}, 14^{\circ} \mathrm{C}, 13^{\circ} \mathrm{C}, 12^{\circ} \mathrm{C}$ if the existing heating thermostat setting is higher. Simulations were also carried out for all the houses with cooling thermostat at existing settings as shown in Table 2 , and at $26^{\circ} \mathrm{C}, 27^{\circ} \mathrm{C}, 28^{\circ} \mathrm{C}, 29^{\circ} \mathrm{C}, 30^{\circ} \mathrm{C}$, $31^{\circ} \mathrm{C}, 32^{\circ} \mathrm{C}$ if the existing cooling thermostat setting is lower. For each house, simulations were carried out in its corresponding NatHERS CZ for the design with the original wall construction and for the design with the external and internal walls replaced by $300 \mathrm{~mm}$ rammed earth walls, respectively. Thus, a total of 4416 AccuRate 
simulations were executed in this study. The annual heating energy requirement, cooling energy requirement and the total annual heating and cooling energy requirement results presented in this section are the average values of the two houses in each NatHERS CZs.

\section{Results for existing thermostat settings}

Figure 4 compares the heating, cooling and the relative total energy requirements for the houses with original wall systems and rammed earth walls using the existing NatHERS heating and cooling thermostat settings. Here, the relative total energy requirement is the total heating and cooling energy requirement of the house with rammed earth walls divided by the total heating and cooling energy requirement of the houses with the original wall systems in each NatHERS CZ. When investigating the effect of wall construction types on house heating and cooling energy requirements, the mean ambient winter and summer temperatures are important factors. Figure 4 also plotted the mean winter and summer temperatures for each NatHERS CZ.

It was found that for NatHERS CZs with mean ambient winter temperatures below $15.0^{\circ} \mathrm{C}$, the replacement with rammed earth walls generally results in much higher heating energy requirement and slightly low cooling energy requirements with the existing heating and cooling thermostat settings. The reason is that in these NatHERS $\mathrm{CZs}$, heating energy requirement is generally the same magnitude or higher than cooling energy requirement. In order to comply with NCC energy efficiency requirement, external walls are normally insulated with R-values from 1.5 to 3.0. Replacing these insulated external wall systems with rammed earth walls generally results in much higher heating energy requirement due to the low thermal resistance of the latter at R0.24, while the cooling energy requirement is slightly reduced due to the high thermal mass of the rammed earth walls. Consequently, the total energy requirements with rammed earth houses are generally higher than the houses with the original walls as shown in Figure 4 (c).

On the other hand, in climates where there is no or small space heating requirements (NatHERS CZs with mean ambient winter temperatures above $15.0^{\circ} \mathrm{C}$ and mean ambient summer temperatures above $25.5^{\circ} \mathrm{C}$ ), the replacement with rammed earth walls generally results in relatively lower total heating and cooling energy requirement. This is because the high thermal mass of rammed earth walls reduces cooling energy requirement, while there is smaller changes in the heating energy requirement.

In several climates, such as NatHERS CZs 1, 4-6, 32, 37 and 40 (refer to Table 2), concrete blocks were used as the original wall system. The replacement with rammed earth walls can also result in lower total heating and cooling energy requirement due to the high thermal mass of the rammed earth walls and the even lower thermal resistance of the concrete block walls at R0.15 in comparison with the rammed earth walls as listed in Table 3.

\section{Results for different heating thermostats}

Figure 5 shows the relative total energy requirements for the houses in the 69 NatHERS CZs using heating thermostat temperatures at $13.0^{\circ} \mathrm{C}, 15.0^{\circ} \mathrm{C}$ and $17.0^{\circ} \mathrm{C}$ respectively, while the cooling thermostats used the existing settings. The relative total energy requirements using the existing heating thermostat settings were also included for comparisons.

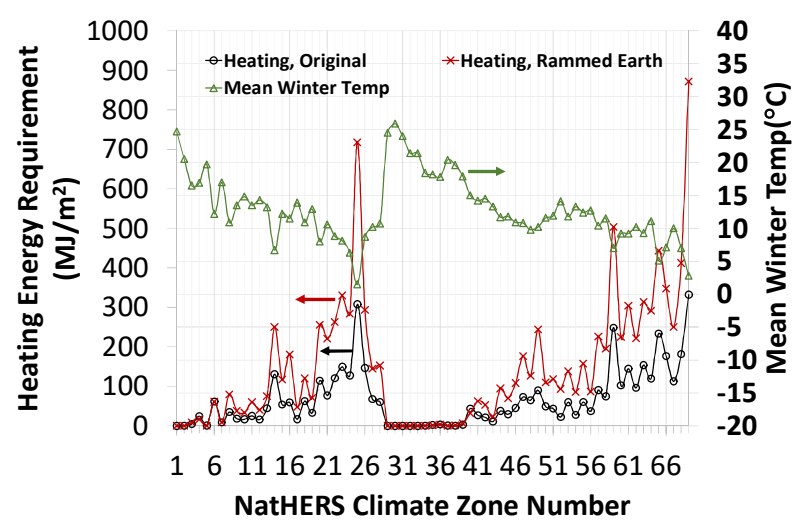

(a) Heating

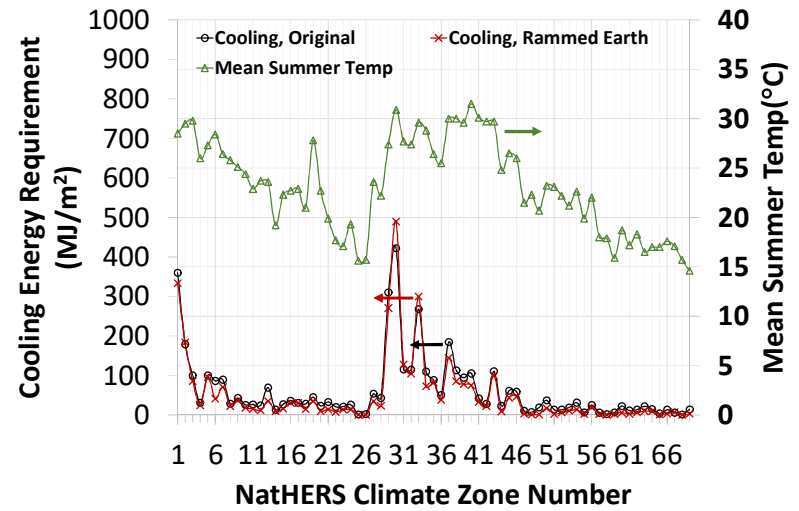

(b) Cooling

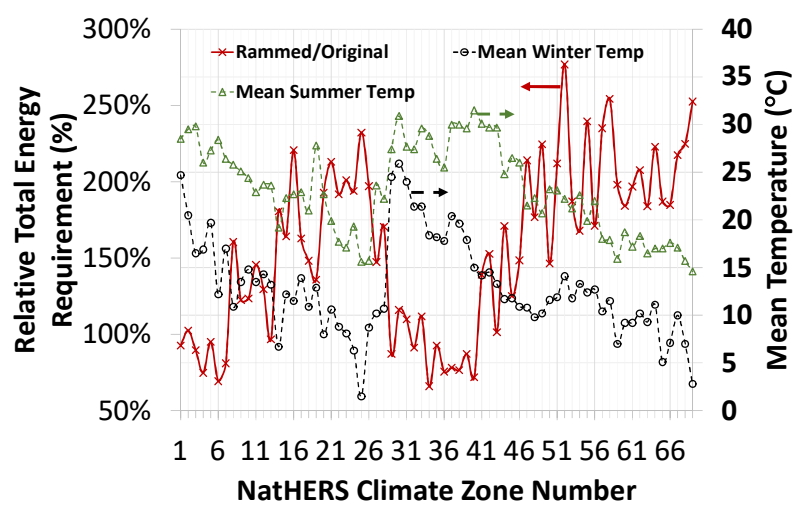

(c) Relative total energy requirements

Figure 4: Energy requirements for space heating (a), space cooling (b) and the relative total energy requirements (c) for the houses with original wall systems and rammed earth walls using the existing NatHERS heating and cooling thermostat settings. 
It was found that the worst thermal performance with rammed earth walls were found in NCC CZ8 (including NatHERS CZs 25 and 69) which have the coldest climates (alpine) in Australia with the mean ambient winter temperature between $1.0^{\circ} \mathrm{C}$ and $3.0^{\circ} \mathrm{C}$. For NatHERS CZs 25 and 69 , the replacement using rammed earth walls results in around $150 \%-200 \%$ heating energy requirements increase. Reducing the heating thermostat from existing, $17.0^{\circ} \mathrm{C}, 15.0^{\circ} \mathrm{C}$ to $13.0^{\circ} \mathrm{C}$ does not make much improvement to the relative total energy requirements. Spacing heating is dominant in these climates with minimal summer cooling requirements. The low thermal resistance of the rammed earth wall contributes to this poor performance relative to the original wall systems which have insulation levels at R2.0 or above in these two NatHERS CZs.

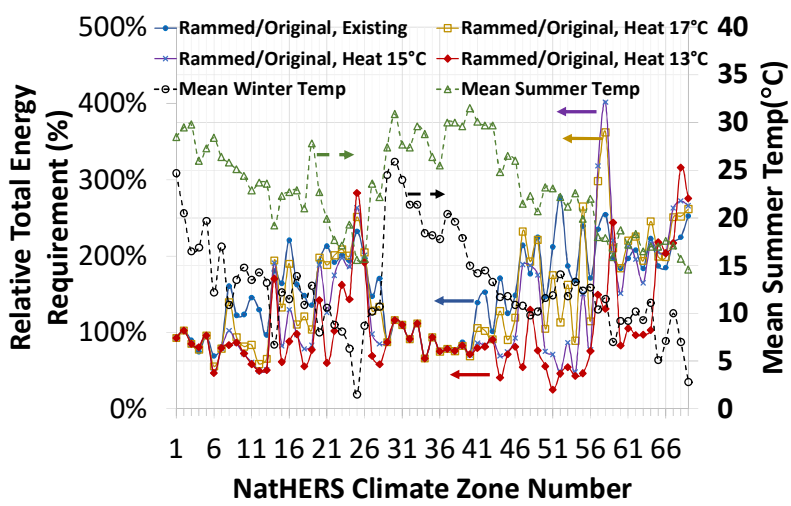

Figure 5: Relative total energy requirements for the houses in the 69 NatHERS CZs using different heating thermostat temperatures at $13.0^{\circ} \mathrm{C}, 15.0^{\circ} \mathrm{C}, 17.0^{\circ} \mathrm{C}$ and existing settings respectively.

For NatHERS CZs with mean ambient winter temperature between 3.0 and $10.0^{\circ} \mathrm{C}$, replacement with rammed earth walls generally results in poor thermal performance in the heating thermostat ranges from 15 to $20^{\circ} \mathrm{C}$. Further reduction in the heating thermostat to between 12 and $15^{\circ} \mathrm{C}$ may make the thermal performance of a rammed earth house comparable to the house with the original wall systems in terms of the total heating and cooling energy requirement as seen in Figure 5. Although there are occupants who operate houses below $15^{\circ} \mathrm{C}$, it is generally not recommended due to health considerations (Shiue and Shiue, 2014; Jevons et al, 2016). These regions include all the NatHERS CZs in NCC CZ7 and some NatHERS CZs in NCC CZ6 (refer to Table 2).

For NatHERS CZs with mean ambient winter temperature between 10.0 and $15.0^{\circ} \mathrm{C}$, the thermal performance of rammed earth wall houses relative to the houses with the original wall systems can be significantly improved by lowering the heating thermostat setting temperature. Rammed earth houses can in general achieve similar or better thermal performances when the heating thermostat is around $15^{\circ} \mathrm{C}$ in comparison with the original house designs. These regions include all the NatHERS CZs in
NCC CZ5 and some NatHERS CZs in NCC CZs 3, 4 and 6.

This finding has several implications. First, in these regions in Australia, the population group, who considers thermally comfortable or prefers a heating thermostat setting temperature at around $15.0^{\circ} \mathrm{C}$, will in theory consume similar or less space heating energy in the rammed earth houses than in the corresponding houses with the original wall constructions. It should be noted that the rammed earth houses in these regions are generally achieve lower star ratings (i.e. predicted to consume more space heating energy) than the houses with the original wall constructions according to NatHERS star rating. Second, the reduction in heating energy consumption for the rammed earth houses is higher than that for the houses with the original wall constructions if the occupants set the heating thermostat temperatures at $15^{\circ} \mathrm{C}$ instead the existing heating thermostat temperatures. This confirms that NatHERS rating does discriminate rammed earth constructions in these climate regions in the view of this particular population group who consider thermally comfortable or prefer a lower heating thermostat temperature at around $15.0^{\circ} \mathrm{C}$.

For NatHERS CZs with mean ambient winter temperatures above $15.0^{\circ} \mathrm{C}$, heating thermostat temperature changes have small effect on the relative total energy requirement of the houses with both wall constructions (rammed earth walls and the original walls). Winters in these regions are relatively mild and warm with no or minimal space heating requirement. Thus, reductions in the heating thermostat temperature have no or very small effect on the total heating and cooling energy requirement in these climates. These regions include all the NatHERS CZs in NCC CZ1, and the majority of the NatHERS CZs in NCC CZ2 and NCC CZ3.

\section{Results for different cooling thermostats}

Figure 6 shows the relative total energy requirements for the houses in the 69 NatHERS CZs using cooling thermostat temperatures at $27^{\circ} \mathrm{C}, 29^{\circ} \mathrm{C}$ and $31^{\circ} \mathrm{C}$ respectively, while the heating thermostats used the existing settings. The relative total energy requirements using the existing heating thermostat settings were also included for comparisons. For NCC CZ8 (including NatHERS CZ 25 and 69) which has the coldest climate in Australia with the mean ambient winter temperature between $1.0^{\circ} \mathrm{C}$ and $3.0^{\circ} \mathrm{C}$, changes in the cooling thermostat temperature do not change the poor performance of the rammed earth wall construction since there is no need of cooling in these regions.

For NatHERS CZs with mean ambient winter temperature between 3 and $15.0^{\circ} \mathrm{C}$, replacing with rammed earth walls generally results in high total energy requirement with all the cooling thermostat temperatures investigated in this study. This is mainly due to the poor performance of houses with rammed earth walls for space heating. It was also observed that with the increase in the cooling thermostat temperature, the relative total energy requirement of the houses becomes higher. This can be 
explained with one of the example houses in Melbourne NatHERS CZ21.

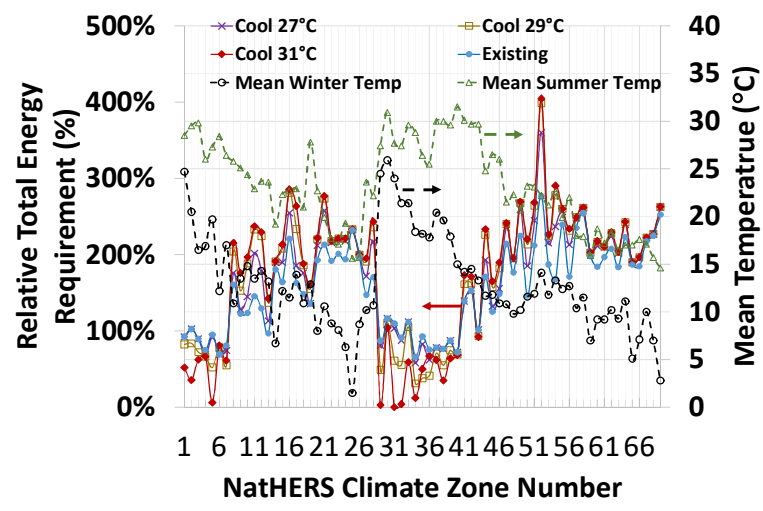

Figure 6: Relative total energy requirements for the houses in the 69 NatHERS CZs using cooling thermostat temperatures at $27^{\circ} \mathrm{C}, 29^{\circ} \mathrm{C}$ and $31^{\circ} \mathrm{C}$ respectively.

Table 4 lists the total annual heating and cooling energy requirement per $\mathrm{m}^{2}$ of conditioned floor area for the brick veneer house (refer to Table 2) with original wall system and rammed earth walls at the existing and at $27^{\circ} \mathrm{C}$ cooling thermostat temperatures respectively in Melbourne. This three-bedroom two-storey house has R2.5 insulation in its original external brick veneer wall construction. It was found that the cooling energy requirement was already reduced with the replacing of the original wall system by rammed earth walls at the existing cooling thermostat temperature which is $24^{\circ} \mathrm{C}$ in Melbourne (refer to Table 2). Although the cooling energy requirement is further reduced to around zero (no cooling requirement) for the house with rammed earth walls at $27^{\circ} \mathrm{C}$ cooling thermostat temperature, the reduction in the cooling energy requirement with the original wall system is larger when the cooling thermostat changes from existing $\left(24^{\circ} \mathrm{C}\right)$ to $27^{\circ} \mathrm{C}$. This explains the observation in Figure 6 that the relative total energy requirement of the houses increases if the cooling thermostat temperature is increased. However, it should be noted that rammed earth wall house designs do perform better during summer period and a total removal of space cooling system may be achievable as demonstrated with this sample house in Melbourne as shown in Table 4.

For NatHERS CZs with mean ambient winter temperature above $15.0^{\circ} \mathrm{C}$ and mean ambient summer temperatures above $25.5^{\circ} \mathrm{C}$, replacing with rammed earth walls generally results in better thermal performance with increased cooling thermostat temperature range investigated in this study. This is expected since in these climates, cooling dominates with no or minimal heating requirement, while the high thermal mass of the rammed earth walls may achieve reduction in cooling energy requirement in comparison with the original wall systems.

It was found that when the cooling thermostat is above certain temperature, both the original and the rammed earth houses require no or minimal cooling energy and their performance difference in terms of total heating and cooling energy requirement become small. In other words, the energy performance of the original house design and the house with rammed earth are similar in terms of energy performance.

Consequently, for cooling energy requirement, increasing the cooling thermostat temperature in general can only benefit to rammed earth wall constructions in NatHERS $\mathrm{CZs}$ with mean ambient winter temperature above $15.0^{\circ} \mathrm{C}$ and mean ambient summer temperatures above $25.5^{\circ} \mathrm{C}$.

Table 4: Heating and cooling energy requirement at different cooling thermostat temperatures for one sample house in Melbourne, NatHERS CZ21.

\begin{tabular}{|c|c|c|c|}
\hline & $\begin{array}{l}\text { Heating } \\
\left(\mathbf{M J} / \mathrm{m}^{2}\right)\end{array}$ & $\begin{array}{l}\text { Cooling } \\
\left(\mathrm{MJ} / \mathrm{m}^{2}\right)\end{array}$ & $\begin{array}{l}\text { Relative } \\
\text { Total } \\
\text { Energy } \\
(\%)\end{array}$ \\
\hline Original Wall, existing & 87.4 & 33.7 & \\
\hline $\begin{array}{l}\text { Rammed earth wall, } \\
\text { existing }\end{array}$ & 254.9 & 15.3 & $223 \%$ \\
\hline Original Wall, $27^{\circ} \mathrm{C}$ & 87.3 & 9.1 & \\
\hline Rammed earth wall, $27^{\circ} \mathrm{C}$ & 254.9 & 0.8 & $265 \%$ \\
\hline
\end{tabular}

\section{Discussions}

It is understood that two houses in each climate zone are relatively small sample sizes. It is also noted that rammed earth wall houses may perform better in extreme hot days when the house is in free-run operation with no cooling. On the other hand, although the cooling energy may be reduced in NatHERS CZs with mean summer temperature above $25.5^{\circ} \mathrm{C}$ using rammed earth walls, the high thermal mass in hot climates may result in slow cooling down during sleeping hours in comparison with lightweight wall houses. Further, comparison between rammed earth wall construction and other wall types may need specific house designs which are appropriate for the wall systems used. Therefore, the current study may provide general guidance on the performance of rammed earth wall houses in Australian climates at different heating and cooling thermostat temperatures. The findings provide useful information for building regulators on the potential impact of modifying existing thermostat settings in NatHERS software. However, further detailed research is needed in the future to cover the aspects discussed in this section.

\section{Conclusions}

To answer the question whether the existing NatHERS rating discriminates against rammed earth constructions, simulations were carried for two sample houses each in all NatHERS CZs at different heating and cooling thermostat temperatures for the design with the original wall systems and for the design with rammed earth walls respectively. Results showed that for NatHERS CZs with mean ambient winter temperature between 3.0 and $10.0^{\circ} \mathrm{C}$, replacement using rammed earth walls generally results in poor thermal performance unless reducing the heating thermostat to $12-15^{\circ} \mathrm{C}$ (note that this is not recommended considering health issues). However, for NatHERS CZs with mean ambient winter temperature between 10.0 and $15.0^{\circ} \mathrm{C}$, the population group, who 
considers thermally comfortable or prefer a heating thermostat setting temperature around $15.0^{\circ} \mathrm{C}$, is predicted to consume similar or less space heating energy in the rammed earth houses than that in the houses with the original wall constructions. This confirms that NatHERS rating does discriminate against rammed earth constructions in these climate regions in the view of this particular population group.

For cooling energy requirement, increasing the cooling thermostat temperature in general only benefit to rammed earth wall constructions in NatHERS CZs with mean ambient summer temperatures above $25.5^{\circ} \mathrm{C}$. The findings can provide useful information for building regulators on the potential impact of modifying existing thermostat settings in NatHERS software. Although the study focused on Australia context, the general findings from this study are mainly climate related and should be applicable to locations with similar climates in other countries. Further detailed research is needed in the future by involving more sample houses and by including thermal performance in free-run house operation.

\section{References}

Ambrose, M., James, M., Law, A., Osman, P., White, S. (2013). The Evaluation of the 5-Star Energy Efficiency Standard for Residential Buildings, CSIRO report, Melbourne, Australia.

ASHRAE (2013). ANSI/ASHRAE Standard 55-2013: Thermal Environmental Conditions for Human Occupancy. American Society of Heating, Refrigeration and Air-Conditioning Engineers Inc., Atlanta.

Chen, D., Ren, Z., James, M. (2018). What the indoor air temperatures in houses in three Australian cities tell us? Proceedings of 10th Windsor Conference: Rethinking Comfort, Cumberland Lodge, Windsor, UK, 12-15 April 2018.

Daniel, L. (2017). 'We like to live in the weather': cooling practices in naturally ventilated dwellings in Darwin. Energy and Buildings 158, 549-557.

Daniel, L., Williamson, T., Soebarto, V., Chen, Z.D. (2015b). Learning from thermal mavericks in Australia: comfort studies in Melbourne and Darwin. Architectural Science Review 58(1) 57-66.

Daniel, L., Soebarto, V., Williamson T., (2015a). House energy rating schemes and low energy dwellings: the impact of occupant behaviours in Australia. Energy and Buildings 88, 34-44.

Delsante, A.E. (2005) Is the new generation of building energy rating software up to the task? - A review of AccuRate. Paper presented at $A B C B$ Conference 'Building Australia's Future 2005', Surfers Paradise, 11-15 September 2005.

Department of the Environment and Energy, Australia Government (2018). Australian Energy Update 2018.
James, P., Sonne, J., Vieira, R., Parker, D., Anello, M. (1996). Are energy savings due to ceiling fans just hot air? Proceedings of the 1996 ACEEE Summer Study on Energy Efficiency in Buildings 8, 89-93.

Jevons R., Carmichael, C., Crossley, A., Bone, A. (2016). Minimum indoor temperature threshold recommendations for English homes in winter - A systematic review, Public Health 136, 4-12.

Kim, J., de Dear, R.J., Parkinson, T, Candido, C., Cooper, P., Ma, Z., Saman, W. (2016). Field study of air conditioning and thermal comfort in residential buildings. Proceeding of 9th Windsor Conference: Making Comfort Relevant, Cumberland Lodge, UK, April 7-10, 2016.

Kordjamshidi, M., King, S. (2009). Overcoming problems in house energy ratings in temperate climates: A proposed new rating framework, Energy and Buildings 41, 125-132.

Manning, M.M., Swinton, M.C., Szadkowski, F., Gusford, J., Ruest, K. (2007). The Effects of Thermostat Setback and Setup on Seasonal Energy Consumption, Surface Temperatures, and Recovery Times at the CCHT Twin House Research Facility, ASHRAE Transactions 113(1), 1-12.

O’Leary, T., Belusko, M., Whaley, D., and Bruno, F. (2016). Comparing the energy performance of Australian houses using NatHERS modelling against measured household energy consumption for heating and cooling, Energy and Buildings 119, 173-182.

Ren, Z., \& Chen, Z.D. (2010). Enhanced Air Flow Modelling for AccuRate - A Nationwide House Energy Rating Tool in Australia. Building and Environment 45 (5), 1276-1286.

Ren, Z., \& Chen, Z.D. (2017). Modelling study of the impact of thermal comfort criteria on housing energy use in Australia. Applied Energy 210, 152-166.

Shiue, I., Shiue, M. (2014). Indoor temperature below $18^{\circ} \mathrm{C}$ accounts for $9 \%$ population attributable risk for high blood pressure in Scotland. International Journal of Cardiology 171, e1-e2.

Soebarto, V. (2000). A low energy house and a low rating: what is the problem? ANZAScA 2000: Proceedings of the 34th Conference of the Australia and New Zealand Architectural Science Association, Adelaide, Australia, 1-3 December, 2000.

Walsh, P.J., \& Delsante, A.E. (1983). Calculation of the thermal behaviour of multi-zone buildings, Energy and Buildings 5, 231-242.

Williamson, T., Soebarto, V., Radford, A. (2010). Comfort and energy use in fiveAustralian awardwinning houses: regulated, measured and perceived, Build.Res. Inf. 38(5) 509-529. 